\title{
Towards Developing a Green Manufacturing Environment: What is Ghana doing?
}

\author{
William Gyasi-Mensah (Corresponding author) \\ School of Finance and Economics, Jiangsu University \\ No. 301 Xuefu Road, Zhenjiang, Jiangsu, P.R., 212013, China \\ E-mail: gymmensah@yahoo.com
}

Hu Xuhua

School of Finance and Economics, Jiangsu University

No. 301 Xuefu Road, Zhenjiang, Jiangsu, P.R., 212013, China

E-mail: xuhuahu@163.com

\begin{abstract}
Received: March 14, 2018 Accepted: March 30, 2018 Published: April 13, 2018
doi:10.5296/emsd.v7i2.12814 URL: https://doi.org/10.5296/emsd.v7i2.12814
\end{abstract}

\begin{abstract}
Developed nations embarked on massive industrialization through manufacturing in order to reap the benefits that accompany this developmental strategy. Nations of the developing world are also adopting similar strategies to make the most of their natural resources. Realizing the negative effects of manufacturing on the environment and human lives, nations have began upgrading their manufacturing methods through the adoption of eco-friendly processes. This article intends to throw light on what the developing nation of Ghana has been doing to mitigate the effects of conventional methods of manufacturing on the environment and on human lives. The article presents the relationship between manufacturing and the environment within which manufacturing take place. It also presents some environmental challenges encountered in manufacturing sector in Ghana, as well as steps that are taken to minimize and/or prevent them. The article again presents efforts that have been taken towards integrating green practices in the manufacturing industry in Ghana, through the collaboration between the country and other international stakeholders. The literature on what Ghana is doing to create green manufacturing environment lacks empirical approach to come to a verified conclusion, hence the need to carry out future studies which is empirically based. Other gaps are also presented in the article, and what can be done to fill these gaps is also
\end{abstract}


presented.

Keywords: Green manufacturing, Eco-friendly manufacturing, Development, Ghana

\section{Introduction}

The economy of Ghana cannot be discussed without the vital role played by the manufacturing sector. It serves as a source of huge foreign exchange inflows, supplier of job opportunities to skilled and semi-skilled job seekers, facilitating the growth of poor localities, as well as adding substantially to the earnings of the localities. However, the adverse effect of these manufacturing activities on the environment cannot be underestimated.

Manufacturing companies across the globe have resorted to more environmentally safe enterprise and marketing activities due to the upsurge in the environmental difficulties and increasing public demand to reflect on the effects of their activities in the environment (Kotler, 2011). Strategic approaches have been adopted by several firms to meet the concerns of stakeholders in the manufacturing industry, while producing goods that meet customer expectation regarding environmental safety concerns (Hult, 2011). Among the responses to this change in customer expectations is the alteration in current products while bringing on board new products and processes aimed at minimising environmental effect, but instead improve the environmental protection by firms (Cronin et al. 2011).

With the assertion that integrating green products enhance the efforts of firms towards environmental preservation, maintain a competitive edge, and growth acceleration (Nidumolu et al. 2009), it is anticipated that green product innovation will be much accelerated by companies in the future (Varadarajan 2015). Studies have been conducted under various titles by academicians to find out the motives and processes adopted by firms to innovate in their product lines. Among these titles include green product innovation (e.g. Dangelico et al. 2017), sustainable innovation orientation (e.g., Varadarajan 2015), environmentally conscious product strategies (e.g., Pujari and Wright 1996; Katsikaes et al. 2016), eco-design practices (e.g., Sarkis et al. 2010; Yu et al. 2017), green product development (e.g., Chen 2001; Johansson and Sundin, 2014), environmental new product development (e.g., Pujari et al. 2003; Jabbour et al. 2015) and green product programs (e.g., Leonidou et al. 2013).

It must be emphasized that, this area of research has made significant inputs to the knowledge of green product and processes in firms and marketing. This paper simply aims to review the nature of green practices integration in the Ghanaian manufacturing sector based on available literature from publications and reports from state institutions and international organisations, as this area of study concerning the product manufacturing sectors has received little attention.

\section{The Manufacturing Industry and the Environment}

Manufacturing and the natural ecosystem have always been connected in some manner. Apart from enhancing output of manufacturing firms is the capacity to increase markets for these products, with the aim of making high profits on manufacturing. The ability of some firms such as those in the agro-industry to effect derived demand or accelerate the operations of 
other manufacturers is likely to create sideway linkages, that is, linkages emanating from one firm making use of the by-products or production waste obtained from initial production processes according to the Food and Agriculture Organization (FAO, 1997, Al-hassan et al. 2013).

Discoveries have been made by the FAO (1997) on how manufacturing firms such as those in the agro-processing sector add to the general growth of economies across the globe. Despite these benefits the manufacturing sector also has negative environmental impact. These may include release of toxic waste into water bodies, and the release of toxic gasses into the air, thus affecting the clean air. Though these challenges exist, several nations lack plans and structures that are capable of mitigating these ecological challenges. In the work of Ogbonnaya (2008), he asserted that in Nigeria, agro-processing manufacturing activities present favorable and unfavorable effects on the natural environment, thus requiring conscious processes aimed at effectively reducing and preserving these negative ecological effects.

\subsection{Some Environmental Challenges Encountered in Manufacturing Sector in Ghana}

There are thousands of manufacturing firms in Ghana, half of which are categorized as medium to large scale. The Environmental Protection Agency of Ghana (EPA) opines that, Accra and Tema metropolitan areas of the Greater Accra region are home to about sixty percent of these firms (EPA, 2002). These firms are of vital importance to the local economy and the nation at large. However, these manufacturing locations are not large enough and so suffer from high environmental pressure as a result of the manufacturing operations. These environmental pressures and impacts come in the form of solid waste, air and water toxins.

Manufacturing activities have been producing large volumes of waste in times past. Nevertheless, waste treatment facilities or effective environmental management processes have not been in their best (EPA, 2002). Industrial or manufacturing toxic substances usually released in Ghana have been from the industries such as the food processing, mineral exploitation and processing, petroleum handling and textile industry (EPA, 1991). Among the medium and small scale firms, the sources of toxic substances involve wood processing, edible oil processing, and soap and detergent making firms.

In a study conducted by the EPA (2002), they asserted that the attention given to liquid environmental contamination from manufacturing firms is on the average at excessive levels in six out of twenty one districts located at the coast of Ghana. The reason assigned to this is that, manufacturing activities along in these areas are very intense as happening in Tema and Accra metropolis. Relying on knowledge from two public organisations, District Environmental Plans (DEPs) and Local Environmental Action Plans (LEAPs), an appraisal regarding the levels of environmental contamination challenges from firms was conducted in the coastal industrial areas of Ghana. From this appraisal, mining industries, food/agro processing and material processing were identified as the sectors posing the greatest threat of water pollution in the nation. 


\subsection{Steps at Preventing Negative Impact of Industrial Activities on the Environment}

Some steps have been taken over the years to prevent industrial pollution of the environment to complement the industrialization and green manufacturing drive of the country, through environmental management.

Firm licensing regulation is one of such steps. This exercise is administered by the Environmental Protection Agency in Ghana and it presents an effective approach towards environmental pollution mitigation. Firms that receive this license are expected to supply a framework for a suitable pollution control technology that they plan to integrate into their operations.

Another step aimed at preventing the adverse effect of industrial activities on the environment is Environmental Impact Assessment (EIA). Prior to establishing industries, require decision-making on several factors. Firm owners with the assistance of EIA are able to forecast and analyze the ramifications of intended projects (Ortolano and Shepherd, 1995). A series of nine stages make up EIA, comprising preparatory activities, impact recognition (scoping), baseline study, impact appraisal, mitigation actions, assessment (comparison of alternatives), documentation, decision-making and post auditing (Gbedemah, 2004). An effective implementation of the outcomes of EIA helps to prevent or lesson the negative effects of manufacturing on the environment.

Again, according to Gbedemah (2004), positioning of industrial firms is also another considered approach towards addressing the negative impact of industrial or manufacturing firms. This is to address the unplanned manner that characterises the location of firms in the nation through the creation of industrial and economic zones at specific locations across the country.

The adoption of Pollution Prevention technologies is another step to curtail the negative effect of industrial pollution on the environment. It comprises the reclamation of production waste for reuse, process alteration, product upgrade and equipment redesign. However, these are being carried out on small, individual or firm levels. With some firms having obsolete equipment, some of these instructions have become non-enforceable.

\section{Attempts at integrating Green Practices in the Manufacturing Industry in Ghana}

Having realized the advantages and disadvantages, countries that have embarked on intensive industrialisation or manufacturing of products started creating green economies, especially in the manufacturing sector decades ago. To ensure their operations pose little or minimum threat to the environment and human lives, theses firms in these industrialised countries resorted to adopting contemporary forms of technologies to manufacture and supply the demands of consumers as well as financing new processes of production. Nevertheless, nations in Africa have with the aim of industrializing have also been making good progress by adopting green or environmentally friendly processes, whilst doing away with the conventional technologies which pose negative effects on the environment. Ghana is no exception in this continental effort. The green phenomenon is a study area that has not gained much attention among manufacturers and researchers in Ghana, and so there seem to be 
scanty academic literature development in this study area of green manufacturing by researchers. Therefore, for the purpose of this review, the researcher will make use of reports and working papers put together by recognized international bodies, civil society organisations (CSOs), relevant state institutions and other relevant reports that have focused on the green manufacturing practices in Ghana in order to give an overview of the trend in Ghana.

In a Country Implementation document released in April 2015, the United Nations Environmental Program (UNEP) in partnership with United Nations Development Program (UNDP), United Nations Office for Project Services (UNOPS) and other regional and national partners implemented what was known as Switch Africa Green Project with funding support from European Commission (Switch Africa Green, 2015).

Ghana, in addition to five other nations in Africa is receiving support from the Switch Africa Green Project, with the aim of achieving sustainable development through changes into green economy, which include manufacturing. This measure is sustainable consumption and manufacturing standards based, at the same time enhancing growth, generating suitable employment and minimising economic hardships. This intention of this green project is to aid the public and private sectors to lead an all-round green growth, which includes the manufacturing sector.

Already, Ghana has been making favorable approaches aimed at creating a green economy through national policies, blueprints and initiatives in accordance with the country's sustainable development goals. In order to achieve this green goal and sustain progress in revenue and jobs creation, it requires a transformation from linear economy into a circular economy, facilitated by consciously sustained political commitment and quality governance.

The Ghanaian economy has a productive sector that is classified into Agriculture, Industry and Sectors as contained in the Growth and Poverty Reduction Strategy (GPRS II, 2005) of the National Development Planning Commission (NDPC) document. The Gross Domestic Product (GDP) of 2012 that recorded a contribution of $27.3 \%$ from the industrial sector. This sector comprises five sub-sectors which include electricity generation and supply, manufacturing, Mining and Quarrying. The manufacturing sector contributed $6.9 \%$ to the GDP in 2012. Prior to 2012, the additions of the manufacturing sector to the economy had stagnated four years earlier according to the State of Ghana's Economy (SoGE, 2012).

The manufacturing sub-sector in Ghana comprises several economic activities such as food manufacturing, apparel and leather products, textiles, beverages, tobacco products, furniture and wood products, non-ferrous metal goods and chemical products. However, the components of this sub-sector set out to exhibit a manufacturing industry that is at its premature level of growth (Osei-Amponsah and Anaman, 2008) and is still evolving.

The environmental challenges which have been encountered in the country have had their source from the manufacturing sector, contributing a great deal of green house gas emissions and toxins (UNEP, 2000). The effect of this is that, it has left huge traces of unwholesome sites thereby causing a situation that is capable of affecting human health and the 
environment negatively. With the embracing of Agenda 21 and the associated conventions in 1992, Ghana supported the extensive global policy on the importance to reach sustainable approaches of development. The two major problems facing this sector are the challenge of seeing to the preservation of eco resources in a cost efficient way and, seeing to it that the manufacturing sector reacts to global environmental patterns and benchmarks.

In the document of the Switch Africa Green, (2015), it posits that the undeveloped nature of manufacturing methods in Ghana was shown by the World Economic Forum's Global Competitiveness Report (2012-13). Nonetheless, the manufacturing sector of Ghana's economy for some years now, has effectively integrated a number of Sustainable Consumption and Production (SCP) initiatives into their operations. These include operationalizing the measures that curtail pollution, such as cleaner manufacturing methods and resource efficient production approaches. However, these are few instances, which require further maximization in their application and continuous creation of new green methods.

In an effort to green manufacturing and Ghana's economy in general, Partnership for Action on Green Economy (PAGE) asserts that, manufacturing companies are requested to track the emission of their pollutants and communicate the recorded statistics to the EPA. Again, frequent checks are conducted on firms by the EPA to ensure that they are adhering to the standards of the EPA. In order to strengthen and encourage firms to stick to high standards of environmentally friendly manufacturing in their operations, the EPA introduced what came to be known as the AKOBEN initiative to monitor, assess and reward firms, using a five-color rating scheme. The objective for this initiative was to encourage firms from all sectors that engage in activities that are likely to impact negatively on the environment to adopt clean processes for operations. It was also to improve adherence with environmental regulations though the application of green processes in manufacturing activities (PAGE, 2015).

The effort of Ghana to green the economy and in this case the manufacturing sector also includes the energy and water usage in manufacturing. This is guided by energy and water policies that focus on guarantees of the utilization of energy and water in all the sectors of the economy especially in the manufacturing sector. Commitment to this step has been exhibited by the setting up of the Ghana national Cleaner Production Centre (GNCPC) serves a vital base to help in this upgrade and duplication of these strategies in the other sub-sectors within the manufacturing sector, while coming up with internal standard activities and matrices for propelling extensive acceptance by firms (Switch Africa Green, 2015).

According to the same report of the Switch Africa Green (2015), the use of renewable energy sources is included in the Industrial Policy with the aim of generating business and job openings, with the long-term aim of creating a favorable environment. The aim is to lessen the utilization of fossil fuels, such as biomass and kerosene as seen in most rural locations, lessen the degree of emission of green house gases (GHG), enhance the health of humans and minimise degree of deforestation. The policy appreciates how vital sufficient, efficient and economical electricity and all forms of renewable energy and water supplies are for industrial growth and sustainability of the environment. Again, the policy seeks to assist in generating 
and operationalizing energy and water efficiency and sustainability initiatives. With assistance from the Organization for Economic Co-operation and Development (OECD) under the Climate Technology Initiative (CTI), certain appropriate technologies were recognized, and they have been concentrated on and advanced into a Technology Transfer and Acquisition Plan (TTAP), with the objective to manufacture and utilize products with less or no threat on the environment.

Over a few years now, firms in Ghana have been become conscious of the pressure to go green in the production of their products, as experienced in the developed and industrialised nations that are creating environmentally sustainable processes into their business operations. This has become necessary, especially when they have realized that, marketers and consumers alike have developed taste for green products. Manufacturing firms that serve as suppliers for international wholesale and retail firms such as Koala, Shoprite, Melcom, Game, Max Mart and several others, are supplying green product as they risk losing these marketing clients, while these shops also risk losing their customers whose taste for eco-friendly products have increased. Businesses in Ghana have other vital reason to adopt green manufacturing practices. Based on the experience of firms that have embraced green manufacturing already, adopting green practices, and if adopted well, assists businesses to increase their returns (Rehman et al. (2013).

Rehman et al. (2013) further suggests that, if a company seeks to obtain good financial returns, just as others have benefited, that company has to abide by some salient procedures. Most importantly, it has to dedicate itself to adopting green principles and successfully integrate green manufacturing practices into the lifecycle of its produced goods and operations of its chain of supply. Again, Ramakrishnan (2006) asserted that, it is necessary for prime industries or firms to pay attention to minimising the amount of energy they utilize, amount of water they use, the degree of toxic substance discharges, as well as waste reduction.

\section{Conclusion and Gaps}

The industrial sector of every country, especially the manufacturing sub-sector produces a lot of post manufacturing materials that have a huge negative effect on the environment and human health, especially when conventional methods are used. With its industrialisation motive, Ghana stands the risk of suffering these negative effects like her industrialised counterparts hence the need to adopt green practices in its manufacturing sector, and supply products that are environmentally friendly.

The alarming environmental consequences suffered by industrialised countries has pushed, the government, environmentally concerned organisations, civil society groups, as well as development partners to begin finding effective strategies to educate firms, enact regulation and collaborate with stakeholders to adopt and integrate green manufacturing practices into their operations. The aim is to help contain and end the negative impact of manufacturing activities on the environment.

Government and stakeholders in the manufacturing industry ought to go further to ensure that 
green manufacturing comes to stay by paying attention to it. It is necessary for conscious collaboration between government and actors in the manufacturing sector to support in-house and external research and development towards creating new processes and products that have little or no effect on the environment. This partnership should also be used to fund extensive scientific research at educational institutions through industry-university collaboration research. In this way, several innovative methods of protecting the environment can be identified and integrated into the manufacturing industry, while it supports the growth of the nation's Gross Domestic Product (GDP). Furthermore, through such collaborative scientific research, the state can introduce advanced national green and environmentally safe policies that will be useful in regulating the operations of all firms in Ghana, such as small, medium and large firms.

Though, green manufacturing is adopted as one way of curbing the effects of conventional manufacturing methods, they equally have positive impact on firms that adopt, as well as the economy in general. However, the academia in Ghana has not taken enough keen interest in this research direction. The relatively limited previous studies have been carried out in the form of reports through the funding of international bodies and interested organisations.

Despite the information contained in the literature attribute to the Environmental Protection Agency in Ghana, it must be emphasized that it suffers from lack of a scientific methodology out of which a critical analysis could be carried out and conclusions made accordingly. It was basically a report based document, though the subject matter was one that needed a critical research to address for sound analysis and conclusion.

The other literature document being one from sources which this author found necessary to consult was not overly different from the EPA document in terms of their methodology. The document was equally deficient in terms of scientific methodology needed to draw strong and sound conclusions on subject matters such as the one being looked at. These make the available report findings or information not empirically based for critical and persuasive conclusions. For instance, the literature does not present information on the outcome of these efforts that have been undertaken to integrate green manufacturing practices in the manufacturing sector; neither does it stipulate which firms have implemented these green manufacturing strategies in-house. Therefore, it is necessary for a more empirically based studies on the green manufacturing phenomenon, but one restricted to the Ghanaian manufacturing setting, whereby a rigorous methodology will be applied to gather data which will be taken through empirical analysis in order to present a more scientific outcomes.

Again, the importance of theories in academia cannot be underestimated. However, the literature does not support this assertion especially in the Ghanaian context as no or very limited research has been conducted on the green practices, specifically in the manufacturing sector. Most literature in this path of study related to the Ghanaian manufacturing landscape lacks theoretical backing and hence making its findings weak for conclusions. It is expected that, this review will create the necessary interest for further theory backed studies on green manufacturing in Ghana.

With a conclusion drawn from empirically conducted research, steps can be taken and 
recommendations made to the government and to industry actors (manufacturers) based on the best practices towards creating green manufacturing environment and green economy in general.

\section{References}

Al-hassan, S., Yussif, A-R., \& Mohammed, F. (2013). New Ways of Protecting the Environment: The Case of Agro-Processors in Ghana. Journal of Economics and Sustainable Development, 4(7).

Chen, C. (2001). Design for the environment: A quality-based model for green product development. Management Science, 47(2), 250-263.

https://doi.org/10.1287/mnsc.47.2.250.9841

Cronin, J. J., Jr., Smith, J. S., Gleim, M. R., Ramirez, E., \& Martinez, J. D. (2011). Green marketing strategies: an examination of stakeholders and the opportunities they present. Journal of the Academy of Marketing Science, 39(1), 158-174.

https://doi.org/10.1007/s11747-010-0227-0

Dangelico, R. M., Pujari, D., \& Pontrandolfo, P. (2017). Green Product Innovation in Manufacturing Firms: A Sustainability-Oriented Dynamic Capability Perspective. Business Strategy and the Environment, 26(4), 490-506. https://doi.org/10.1002/bse.1932

Environmental Protection Agency (1991). Ghana Environmental Action Plan, 1. Environmental Protection Agency, Accra, Ghana. Retrieved from:

https://www.lumes.lu.se/sites/lumes.lu.se/files/gbedemah_francis.pdf

Enviromental Protection Agency (2002). State of Environment Report 2001. Environmental Protection Agency, Accra, Ghana. Retrieved from:

https://www.lumes.lu.se/sites/lumes.lu.se/files/gbedemah_francis.pdf

Food and Agriculture Organisation. (1997). "The State of Food and Agriculture”: FAO Corporate Document Repository. By: Economic and Social Development.

Gbedemah, F. S. (2004). Environmental Management System (ISO 14001) Certification in manufacturing companies in Ghana: Prospects and Challenges. (Unpublished master's thesis). Lund University, Sweden.

Hult, G. T. M. (2011). Market-focused sustainability: market orientation plus. Journal of the Academy of Marketing Science, 39, 1-6. https://doi.org/10.1007/s11747-010-0223-4

Jabbour, C. J. C., Jugend, D., de Sousa Jabbour, A. B. L., Gunasekaran, A., \& Latan, H. (2015). Green product development and performance of Brazilian firms: measuring the role of human and technical aspects. Journal of Cleaner Production, 87, 442-451.

https://doi.org/10.1016/j.jclepro.2014.09.036

Johansson, G., \& Sundin, E. (2014). Lean and green product development: two sides of the same coin? Journal of Cleaner Production, 85, 104-121.

https://doi.org/10.1016/j.jclepro.2014.04.005 
Katsikeas, C. S., Leonidou, C. N., \& Zeriti, A. (2016). Eco-friendly product development strategy: antecedents, outcomes, and contingent effects. Journal of the Academy of Marketing Science, 44(6), 660-684. https://doi.org/10.1007/s11747-015-0470-5

Kotler, P. (2011). Reinventing marketing to manage the environmental imperative. Journal of Marketing, 75(4), 132-135. https://doi.org/10.1509/jmkg.75.4.132

Leonidou, C. N., Katsikeas, C. S., \& Morgan, N. A. (2013). Greening the marketing mix: do firms do it and does it pay off? Journal of the Academy of Marketing Science, 41(2), 151-170. https://doi.org/10.1007/s11747-012-0317-2

Nidumolu, R., Prahalad, C. K., \& Rangaswami, M. R. (2009). Why sustainability is now the key driver of innovation. Harvard Business Review, 87(9), 56-64.

Ortolano, L., \& Shepherd, A. (1995): Environmental Impact Assessment: challenges and opportunities. Impact Assessment, 13(1), 3-30.

https://doi.org/10.1080/07349165.1995.9726076

Osei-Amponsah, C., \& Anaman, K. A. (2008). Causal linkages between the growth of the Manufacturing Industry and the Growth of the Macro economy in Ghana (No. 18). Institute of Economic Affairs.

Partnership for Action on Green Economy (2015). Ghana: Green Industry and Trade Assessment. [Online] Retrieved from:

https://www.unido.org/sites/default/files/2016-02/GITA_Ghana_0.pdf

Pujari, D., \& Wright, G. (1996). Developing environmentally conscious product strategies: A qualitative study of selected companies in Germany and Britain. Marketing Intelligence \& Planning, 14(1) 19- 28. https://doi.org/10.1108/02634509610106205

Pujari, D., Wright, G., \& Peattie, K. (2003). Green and competitive: influences on environmental new product development performance. Journal of Business Research, 56(8), 657-671. https://doi.org/10.1016/S0148-2963(01)00310-1

Ramakrishnan, L. (2006, March 7). FIEMA, C. Env. Regional Environmental Coordinator Philips Lighting, Asia. [Online] Retrieved from:

http://www.igpn.org/workshop/pdf/Philips_GreenMfgring. pdf.

Rehman, M. A. A., Shrivastava, R. R., \& Shrivastava, R. L. (2013). Validating Green Manufacturing (GM) Framework for Sustainable Development in an Indian Steel Industry. Universal Journal of Mechanical Engineering, 1(2), 49-61.

https://doi.org/10.13189/ujme.2013.010204

Sarkis, J., Gonzalez-Torre, P., \& Adenso-Diaz, B. (2010). Stakeholder pressure and the adoption of environmental practices: The mediating effect of training. Journal of Operations Management, 28(2), 163-176. https://doi.org/10.1016/j.jom.2009.10.001

Switch Africa Green Country Implementation Document (2015, April). [Online] Retrieved from: 
https://ecobpc.org.gh/cms/news/doc/Ghana\%20Country\%20Strategy\%20Document.SAG.pdf

The State of the Ghanaian Economy (2012). [Online] Retrieved from: https://ecobpc.org.gh/cms/news/doc/Ghana\%20Country\%20Strategy\%20Document.SAG.pdf

United Nations Environment Program Report (2000). [Online] Retrieved from: https://ecobpc.org.gh/cms/news/doc/Ghana\%20Country\%20Strategy\%20Document.SAG.pdf

Yu, W., Ramanathan, R., \& Nath, P. (2017). Environmental pressures and performance: An analysis of the roles of environmental innovation strategy and marketing capability. Technological Forecasting and Social Change, 117, 160-169.

https://doi.org/10.1016/j.techfore.2016.12.005

\section{Copyright Disclaimer}

Copyright for this article is retained by the author(s), with first publication rights granted to the journal.

This is an open-access article distributed under the terms and conditions of the Creative Commons Attribution license (http://creativecommons.org/licenses/by/3.0/). 